\title{
Vulnerability of Smallholder Farmers to Climate Change: A Case Study from Hakwatuna-Oya Irrigation Scheme in Sri Lanka
}

\author{
D.M.N. Diyawadana ${ }^{*}$, S. Pathmarajah ${ }^{1}$ and E.R.N. Gunawardena ${ }^{1}$ \\ Postgraduate Institute of Agriculture \\ University of Peradeniya \\ Sri Lanka
}

\begin{abstract}
A system is said to be vulnerable when it is unable to cope with the adverse effects of climate change, including climate variability. Vulnerability is widely used in development and adaptation contexts. Policies, institutions and other types of interventions and initiatives from the government have a notable influence on the vulnerability of the population. Hakwatuna-oya major irrigation scheme in Sri Lanka was selected for the study to identify the socio-economic and socio-demographic factors affecting the vulnerability of smallholder farmers to climate change or variability. Primary and secondary data were collected in all the 17 GN divisions. A composite index of vulnerability was developed and mapped the vulnerability according to the index. Out of the 17 GN divisions, 6 GN divisions, namelyBogolla, Indigolla, Siyambalawewa, Elagamuwa, Rambe and Thambuwawere moderate to highly venerable. Vulnerable GN divisions account for $38 \%$ of the land area and $41 \%$ of the population. Vulnerability is influenced by many socio-economic factors in the area.
\end{abstract}

Keywords: Climate change, Hakwatuna-oya,smallholder farmer, vulnerability, vulnerability index

\section{INTRODUCTION}

Vulnerability is defined by IPCC as "the degree to which a system is susceptible to, or unable to cope with the adverse effects of climate change, including climate variability and extremes". It is a function of the character, magnitude, and rate of climate variation to which a system is exposed, its sensitivity, and its adaptive capacity (IPCC, 2001; IPCC, 2007). Therefore, the vulnerability of a system depends on internal characteristics (sensitivity and adaptive capacity) of the population and the external factors as climate hazards.

Vulnerability is widely used in development and adaptation contexts. Policies, institutions and other types of interventions and initiatives from the government have a notable influence in internal characteristics of the population. Therefore, key vulnerabilities identified by vulnerability assessment can guide policy makers and implementer to identify the geographic areas and groups of people that have to prioritized and focused. Further, vulnerability assessment facilitates to identify the factors contributing to increase the vulnerability. This helps for better policy decisions and implementations to focus on the real need of the specific group. Therefore, this study was formulated to identify the socio-

\footnotetext{
1 Department of Agricultural Engineering, Faculty of Agriculture, University of Peradeniya, Sri Lanka

* Corresponding author: maheshdmn@gmail.com
} 
economic and socio-demographic factors affecting the vulnerability of smallholder farmers to climate change or variabilityatGramaNiladhari (GN) division level.

\section{METHODOLOGY}

According to FAO, "smallholder farmer" is defined as; "Farmers those who depend on small-scale subsistence farming as their primary source of income. The average size of operational holdings (actual area cultivated) is only 0.8 hectares ( 2 acres) or less" (Thapa, 2009).

\section{Selection of sample}

Hakwatuna-oya major irrigation scheme was selected for the study. The scheme is situated within the Daduruoya river basin and within the Divisional Secretariat of Polpithigama in the Kurunegala district. It has 3020 farm families distributed over 17 GramaNiladhari (GN) administrative divisions (Figure 1).

\section{Data collection}

Primary and secondary data were collected in all the 17 GN divisions using semi-structured questionnaire, key informant interviews and field observations. Secondary data were collected through government officials who are working in the area. Semi-structured questionnaire was developed to gather data on five themes, namely socioeconomic characteristics of farmers, cultivation information, perception to the climate variability, adaptation measures for climate variability and government policy interventions. Questionnaire survey was conducted in every GN division. The population was stratified based on GN divisions and stratified random sampling technique was used to identify the number of households to be surveyed in each GN division. Table 1 shows the distribution of sample units in each GN division. Only the households who are cultivating paddy as a primary or secondary income source were interviewed. Individuals for interviewing were selected randomly within the GN division. Altogether, 298 households were interviewed. Collected data were first filtered based on the land area cultivated (holdings that are less than 2 ac.) and main income source (agricultural) to identify smallholder farmers. 


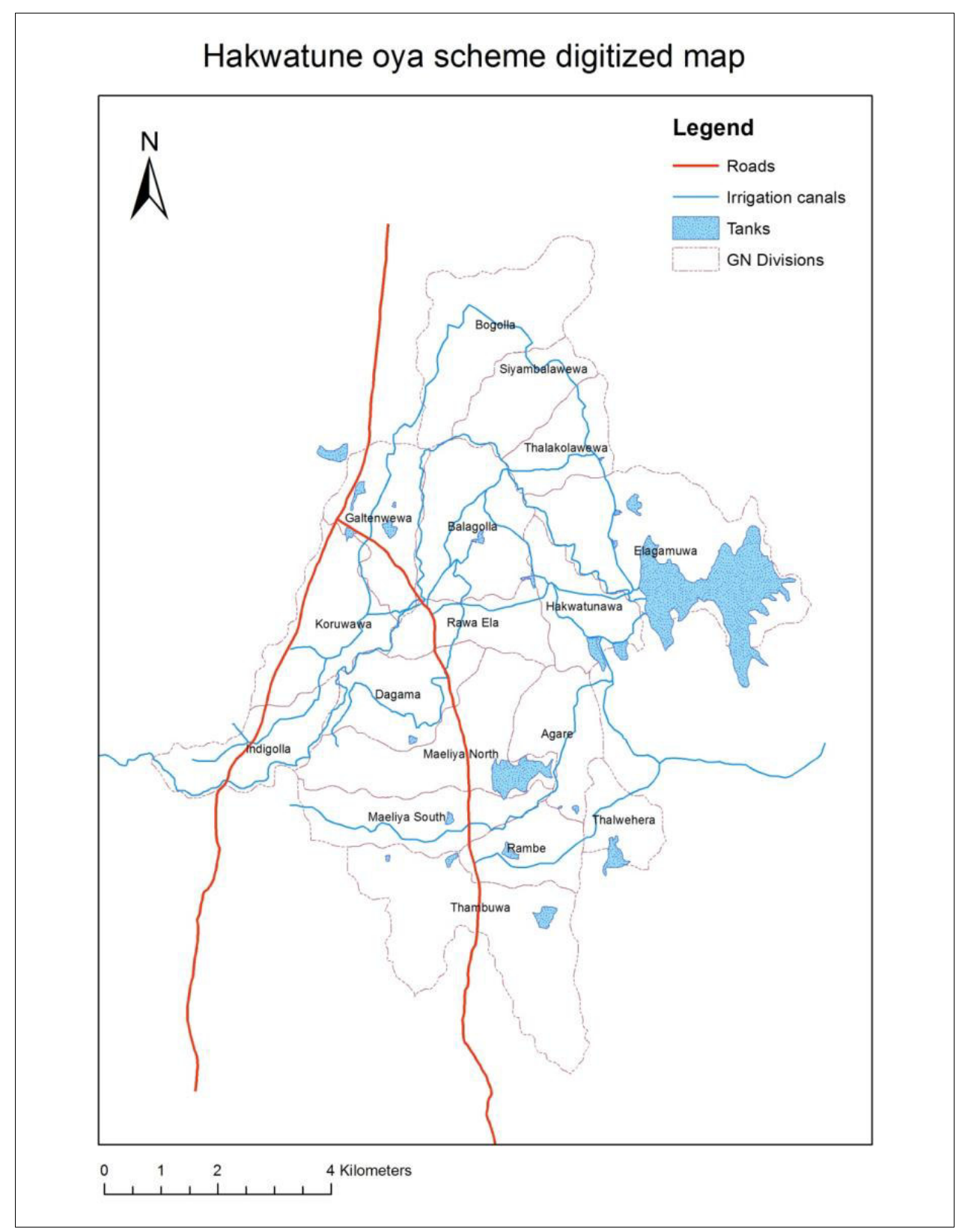

Fig. 1. Map of theHakwatuna-oyairrigation scheme 
Table 1. Sample size at GN division level for household survey

\begin{tabular}{llcccc}
\hline GN division & GN Code & $\begin{array}{c}\text { Land area } \\
\text { (ha) }\end{array}$ & $\begin{array}{c}\text { No. of farm } \\
\text { families }\end{array}$ & Sample size \\
1 & Agare & 373 & 185 & 113 & 11 \\
2 & Balagolla & 368 & 612 & 254 & 25 \\
3 & Bogolla & 352 & 399 & 350 & 35 \\
4 & Dagama & 370 & 313 & 145 & 14 \\
5 & Elagamuwa & 398 & 332 & 191 & 19 \\
6 & Galtanwawa & 366 & 291 & 308 & 31 \\
7 & Hakwatunawa & 395 & 220 & 195 & 19 \\
8 & Indigolla & 367 & 502 & 244 & 24 \\
9 & Koruwawa & 365 & 345 & 220 & 22 \\
10 & MaeliyaDakuna & 372 & 352 & 216 & 21 \\
11 & MaeliyaUthura & 371 & 252 & 135 & 13 \\
12 & Rambe & 374 & 85 & 83 & 8 \\
13 & Rawaela & 369 & 122 & 60 & 6 \\
14 & Siyambalawewa & 396 & 133 & 234 & 23 \\
15 & Thalkolawawa & 397 & 130 & 81 & 8 \\
16 & Thalwahara & 392 & 51 & 30 & 3 \\
17 & Thambuwa & 387 & 169 & 160 & 16 \\
\hline & Total & & $\mathbf{3 0 1 9}$ & $\mathbf{2 9 8}$ \\
\hline
\end{tabular}

\section{Vulnerability assessment}

Index based approach for vulnerability assessment was used in the study. A composite index of vulnerability was developed. The framework developed by IPCC was used as the base for assessing the vulnerability (IPCC, 2007). According to this framework, vulnerability is a function of exposure, sensitivity and adaptive capacity.

Vulnerability $=\mathbf{f}($ exposure, sensitivity, adaptive capacity)

where;

Exposure - The nature and degree to which a system is exposed to significant climatic variations.

Sensitivity - The degree to which a system is affected, either adversely or beneficially, by climate related stimuli.

Adaptive capacity - Potential or ability of a system, region, or community to adjust to the impacts of climate change. 
Exposure and sensitivity affect vulnerability positively and adaptive capacity affects negatively. Only sensitivity and adaptive capacity were considered as the components in calculating the vulnerability index. Exposure was not included in this study for calculating the vulnerability index, as it is difficult to collect rainfall and temperature data separately for each and every GN divisions in the Hakwatuna-oya scheme due to unavailability of rainfall data in each GN division. Further, considerable difference in rainfall among each GN division cannot be expected as the geographic area under consideration is small.

Proxy variables for each component of sensitivity and adaptive capacity were identified and the relationship between proxy variables and vulnerability was established (Table 2)based on available literature (Eriyagama, 2010; MoE, 2011; Punyawardena, 2013). Five proxy variables were used to calculate sensitivity component index and nine proxy variables were used to calculate adaptive capacity component index.

All the proxy variables of sensitivity were categorized into two sub-indicators as human sensitivity and livelihood sensitivity. Similarly, all the adaptive capacity proxy variables were categorized into two sub-indicators as socio-economic adaptive capacity and infrastructure adaptive capacity (Figure2).

Variables were calculated with secondary and primary data as shown in Table 2 Considering the relationship of the variable to the final vulnerability, normalization was done using Equations 1 and 2. If the relationship is positive, Equation 1 was used and if the relationship is negative, Equation 2 was used.

$X=\frac{X a c-X \min }{X \max -X \min } X 100 \ldots \ldots \ldots \ldots,(\mathrm{Eq}, 1)$

$X=\frac{X \max -X a c}{X \max -X \min } X 100 \ldots \ldots \ldots \ldots,(E \mathbf{q}, \mathbf{2})$

Where;

$\mathrm{X}=$ normalised value of the variable

$\mathrm{Xac}=$ actual value of the variable

$\mathrm{Xmin}=$ minimum value of the variable of the dataset

$\mathrm{X} \max =$ maximum value of the variable of the dataset 
Table 2. Variables used in vulnerability assessment

\begin{tabular}{|c|c|c|c|c|}
\hline Indicators & Variables & $\begin{array}{l}\text { Relationship to } \\
\text { vulnerability }\end{array}$ & Method of calculation & $\begin{array}{c}\text { Source of } \\
\text { data }\end{array}$ \\
\hline \multirow{3}{*}{$\begin{array}{l}\text { Human } \\
\text { Sensitivity }\end{array}$} & Population density & $+\mathrm{ve}$ & Population/Area & Secondary \\
\hline & $\begin{array}{l}\text { Agriculture based } \\
\text { households }\end{array}$ & $+\mathrm{ve}$ & $\begin{array}{l}\text { Agriculture based } \\
\text { HH/Population }\end{array}$ & Secondary \\
\hline & $\begin{array}{l}\text { Agriculture labour } \\
\text { force }\end{array}$ & $+\mathrm{ve}$ & $\begin{array}{l}\text { Agriculture labour } \\
\text { force/Total labour force }\end{array}$ & Secondary \\
\hline \multirow[t]{2}{*}{$\begin{array}{l}\text { Livelihood } \\
\text { Sensitivity }\end{array}$} & $\begin{array}{l}\text { Area cultivated by } \\
\text { agro-wells }\end{array}$ & -ve & $\begin{array}{l}\text { Area cultivated by } \\
\text { agro-wells/ Area GN } \\
\text { division }\end{array}$ & Secondary \\
\hline & Small-scale farming & $+\mathrm{ve}$ & $\begin{array}{l}\text { No of HH cultivating } \\
\text { under } 2 \text { acre paddy } \\
\text { land/ Total no of HH }\end{array}$ & $\begin{array}{l}\text { Questionnai } \\
\text { re }\end{array}$ \\
\hline $\begin{array}{l}\text { Socio- } \\
\text { economic } \\
\text { Adaptive }\end{array}$ & $\begin{array}{l}\text { People educated up to } \\
\text { grade } 5 \text { or above }\end{array}$ & -ve & $\begin{array}{l}\text { No of } \mathrm{HH} \text { educated up } \\
\text { to grade } 5 \text { or } \\
\text { above/Total no of HH }\end{array}$ & $\begin{array}{l}\text { Questionnai } \\
\text { re }\end{array}$ \\
\hline \multirow[t]{6}{*}{ Capacity } & $\begin{array}{l}\text { HH heads suffering } \\
\text { from chronic diseases }\end{array}$ & $+\mathrm{ve}$ & $\begin{array}{l}\text { No of HH heads with } \\
\text { chronic diseases/ Total } \\
\text { No of HH }\end{array}$ & $\begin{array}{l}\text { Questionnai } \\
\text { re }\end{array}$ \\
\hline & Unemployment & $+\mathrm{ve}$ & $\begin{array}{l}\text { People unemployed/ } \\
\text { Population of GN }\end{array}$ & Secondary \\
\hline & $\begin{array}{l}\text { HH with salaried } \\
\text { employments }\end{array}$ & -ve & $\begin{array}{l}\text { No of } \mathrm{HH} \text { with salaried } \\
\text { employments/ } \\
\text { Population of GN }\end{array}$ & Secondary \\
\hline & Dependency ratio & $+\mathrm{ve}$ & $\begin{array}{l}\text { People at dependant } \\
\text { age/ Population of GN }\end{array}$ & Secondary \\
\hline & $\begin{array}{l}\text { Poverty head count } \\
\text { index }\end{array}$ & $+\mathrm{ve}$ & $\begin{array}{l}\text { No of people under } \\
\text { poverty line/Population } \\
\text { of GN }\end{array}$ & Secondary \\
\hline & Landless farmers & $+\mathrm{ve}$ & $\begin{array}{l}\text { No of HH who do not } \\
\text { own paddy lands/ Total } \\
\text { no of HH }\end{array}$ & $\begin{array}{l}\text { Questionnai } \\
\text { re }\end{array}$ \\
\hline $\begin{array}{l}\text { Infrastruct } \\
\text { ure }\end{array}$ & Surfaced road density & -ve & $\begin{array}{l}\text { Length of surfaced } \\
\mathrm{road} / \text { Area of the GN }\end{array}$ & Secondary \\
\hline $\begin{array}{l}\text { Adaptive } \\
\text { Capacity }\end{array}$ & $\begin{array}{l}\mathrm{HH} \text { with assured } \\
\text { drinking water }\end{array}$ & -ve & $\begin{array}{l}\text { HH with own well and } \\
\text { piped water line/Total } \\
\text { No of HH }\end{array}$ & Secondary \\
\hline
\end{tabular}



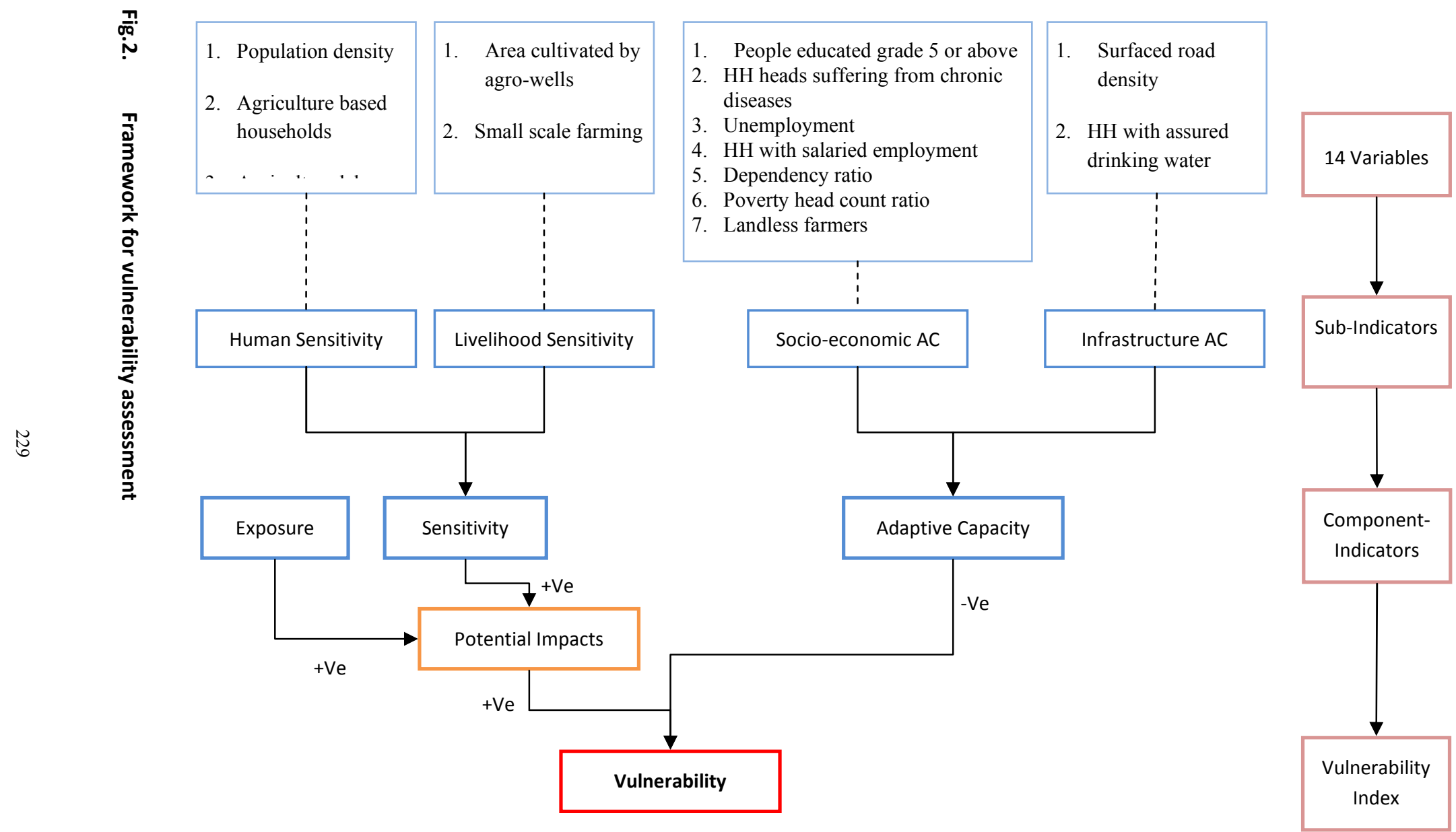
The normalized variables within each sub-indicator were averaged to form each component indicators of the vulnerability index. Then the component indicators were averaged to form the vulnerability index. In averaging, equal weightage was given to all the indicators used.

Each sub-indicator, component indicators and vulnerability index was mapped atGN division level using ArcGIS software. Five severity levels of vulnerability was used to show the final vulnerability levels of each GN division as highly vulnerable, vulnerable, moderately vulnerable, low vulnerable and very low vulnerable. Equal interval technique in ArcGIS software was used to categorize the vulnerability index into the above five severity levels.

\section{RESULTS AND DISCUSSIONS}

\section{Vulnerability of smallholder farmers to climate change}

Figure3 indicates that Indigolla, Maeliya North, Siyambalawewa and ThalwaharaGN divisions are highly vulnerable in terms of human sensitivity. According to Table 3 , high population density and high percentage of agriculture based households are the reasons for high vulnerability in terms of human sensitivity. BogollaGN division is highly vulnerable in terms of livelihood vulnerability. According to the Table 4, less area cultivated by agrowells and high percentage of small-scale farming are the reasons for high livelihood vulnerability. According to the sensitivity index in Figure 3, Bogolla and Indigolla are veryhighly sensitive GN divisions to climate change in the Hakwatuna-oya scheme.

Table 3. Human sensitivity to climate change vulnerability

\begin{tabular}{|c|c|c|c|c|c|}
\hline \multirow{2}{*}{ GN division } & \multicolumn{5}{|c|}{ Normalized variables* } \\
\hline & $\begin{array}{c}\text { Population } \\
\text { density }\end{array}$ & $\begin{array}{c}\text { Agriculture } \\
\text { based } \\
\text { households }\end{array}$ & $\begin{array}{l}\text { Agriculture } \\
\text { labour } \\
\text { force }\end{array}$ & Index value & Rank \\
\hline Agare & 33 & 36 & 18 & 29 & 10 \\
\hline Balagolla & 14 & 22 & 10 & 15 & 15 \\
\hline Bogolla & 0 & 65 & 25 & 30 & 9 \\
\hline Dagama & 26 & 10 & 4 & 13 & 16 \\
\hline Elagamuwa & 3 & 32 & 15 & 17 & 14 \\
\hline Galtanwawa & 42 & 10 & 9 & 21 & 12 \\
\hline Hakwatunawa & 28 & 21 & 10 & 19 & 13 \\
\hline Indigolla & 14 & 100 & 42 & 52 & 2 \\
\hline Koruwawa & 33 & 67 & 29 & 43 & 5 \\
\hline Maeliya North & 56 & 54 & 37 & 49 & 4 \\
\hline Maeliya South & 36 & 0 & 0 & 12 & 17 \\
\hline Rambe & 100 & 18 & 8 & 42 & 6 \\
\hline Rawaela & 42 & 20 & 10 & 24 & 11 \\
\hline
\end{tabular}




\begin{tabular}{llllll}
\hline Siyambalawewa & 29 & 92 & 42 & 54 & 1 \\
Thalkolawawa & 42 & 36 & 17 & 32 & 8 \\
Thalwahara & 67 & 60 & 25 & 51 & 3 \\
Thambuwa & 19 & 57 & 26 & 34 & 7 \\
\hline
\end{tabular}

*If the value of normalized variable is high, its' contribution to vulnerability is also high.

Table 4. Livelihood sensitivity to climate change vulnerability

\begin{tabular}{|c|c|c|c|c|}
\hline \multirow[b]{2}{*}{ GN division } & \multicolumn{4}{|c|}{ Normalized Variables* } \\
\hline & $\begin{array}{l}\text { Area not } \\
\text { cultivated by } \\
\text { agro-wells }\end{array}$ & $\begin{array}{l}\text { Small-scale } \\
\text { farming }\end{array}$ & Index value & Rank \\
\hline Agare & 75 & 19 & 47 & 13 \\
\hline Balagolla & 100 & 44 & 72 & 3 \\
\hline Bogolla & 94 & 100 & 97 & 1 \\
\hline Dagama & 72 & 25 & 48 & 12 \\
\hline Elagamuwa & 100 & 26 & 63 & 5 \\
\hline Galtanwawa & 79 & 31 & 55 & 7 \\
\hline Hakwatunawa & 100 & 30 & 65 & 4 \\
\hline Indigolla & 100 & 58 & 79 & 2 \\
\hline Koruwawa & 100 & 3 & 52 & 10 \\
\hline Maeliya North & 0 & 21 & 10 & 17 \\
\hline Maeliya South & 67 & 9 & 38 & 14 \\
\hline Rambe & 63 & 0 & 31 & 15 \\
\hline Rawaela & 97 & 2 & 49 & 11 \\
\hline Siyambalawewa & 69 & 46 & 58 & 6 \\
\hline Thalkolawawa & 100 & 7 & 54 & 8 \\
\hline Thalwahara & 59 & 2 & 31 & 16 \\
\hline Thambuwa & 93 & 14 & 53 & 9 \\
\hline
\end{tabular}

*If the value of normalized variable is high, its' contribution to vulnerability is also high. 
Diyawadana et al.
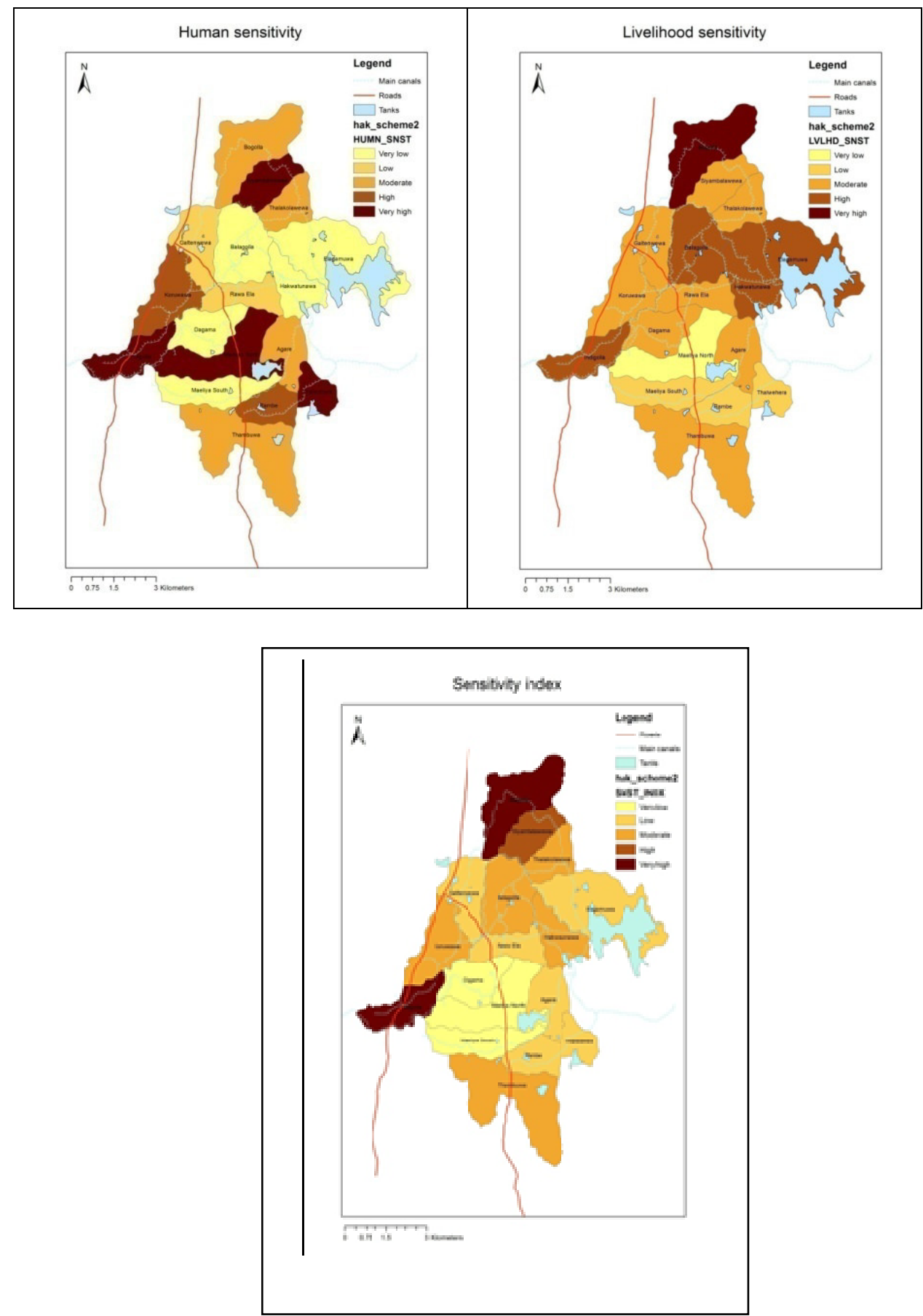

Fig.3. Sensitivity to climate change vulnerability 
According to Figure 4, Bogolla, Galtanwewa and RambeGN divisions are highly vulnerable in terms of socio-economic adaptive capacity. It means, they have least adaptive capacity to climate variability. Rambe and Bogolla have very less percentage of farmers whose income is contributed with government or private salaried employments (Table 5). This leads them to depend more on agricultural sources as the household income. This is one reason for them to become more vulnerable in terms of socio-economic adaptive capacity. Further, Rambe has high percentage of household heads with less educational level (below grade 5) and high percentage of unemployment level, which further reduced the adaptive capacity (Table 5). BogollaGN division has high percentage of households suffering from chronic diseases and high level of poverty head count ratio. These factors have reduced the adaptive capacity of these GN divisions. Therefore, the absence of alternative livelihood opportunities, low educational levels, presence of chronic diseases, unemployment, high dependency ratio and prevalence of high levels of poverty are the reasons for reduced adaptive capacity.

ElagamuwaGN division is highly vulnerable to climate change in terms of infrastructure adaptive capacity. The reason is that this area lack in properly developed road system and has very less percentage of households with assured drinking water (Table 6). These two factors have decreased the adaptive capacity of this area and increased the vulnerability to climate change.

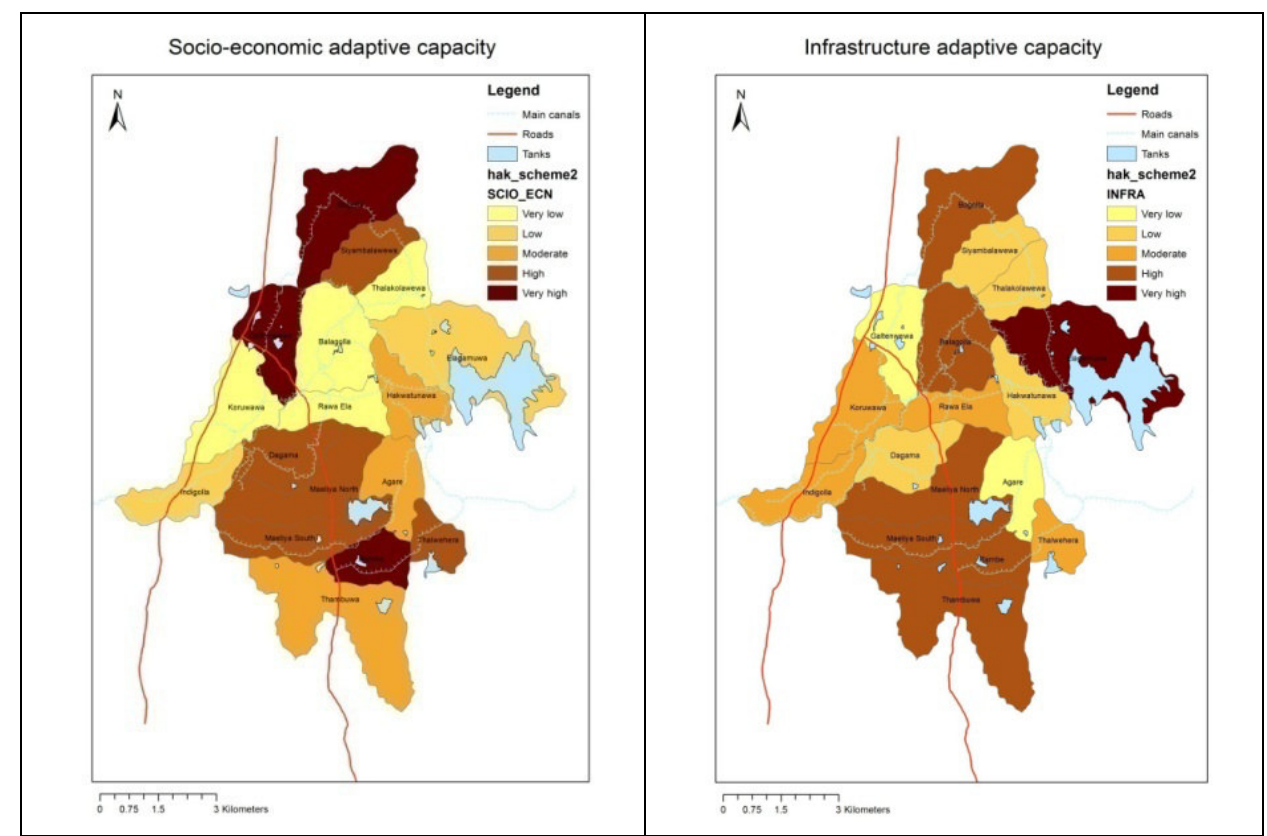


Diyawadana et al.

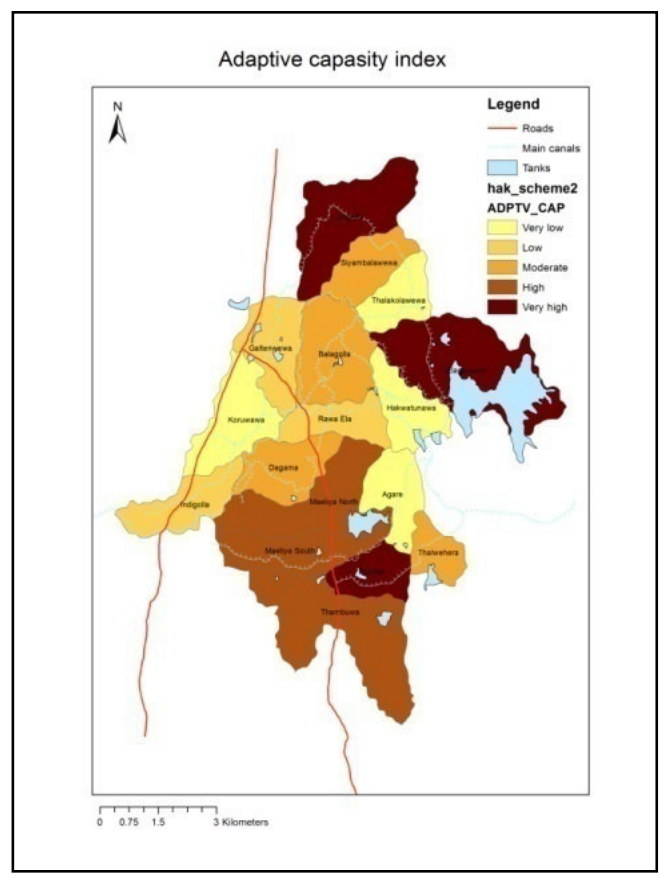

Fig.4. Adaptive capacity to climate change vulnerability

Table 5. Socio-economic adaptive capacity to climate change vulnerability

Normalized Variables*

\begin{tabular}{|c|c|c|c|c|c|c|c|c|}
\hline GN division & $\begin{array}{c}\text { HHnot } \\
\text { educate } \\
\text { d up to } \\
\text { grade } 5 \\
\text { or } \\
\text { above }\end{array}$ & $\begin{array}{c}\text { HH } \\
\text { heads } \\
\text { suffering } \\
\text { from } \\
\text { chronic } \\
\text { diseases }\end{array}$ & $\begin{array}{c}\text { Une } \\
\text { mplo } \\
\text { ymen } \\
\text { t }\end{array}$ & $\begin{array}{c}\text { HH } \\
\text { without } \\
\text { salaried } \\
\text { employ } \\
\text { ments }\end{array}$ & $\begin{array}{c}\text { Depe } \\
\text { nden } \\
\text { cy } \\
\text { ratio }\end{array}$ & $\begin{array}{l}\text { Pover } \\
\text { ty } \\
\text { head } \\
\text { count } \\
\text { index }\end{array}$ & $\begin{array}{c}\text { Landle } \\
\text { ss } \\
\text { farmer } \\
\quad s\end{array}$ & $\begin{array}{c}\text { Ind } \\
\text { ex }\end{array}$ \\
\hline
\end{tabular}

\begin{tabular}{lccccccccc}
\hline Agare & 11 & 69 & 68 & 71 & 45 & 21 & 45 & 47 & 10 \\
Balagolla & 47 & 45 & 0 & 16 & 35 & 61 & 7 & 30 & 16 \\
Bogolla & 57 & 100 & 56 & 85 & 0 & 100 & 69 & 67 & 1 \\
Dagama & 18 & 81 & 93 & 72 & 41 & 29 & 71 & 58 & 4 \\
Elagamuwa & 17 & 60 & 52 & 100 & 41 & 5 & 18 & 42 & 12 \\
Galtanwawa & 62 & 76 & 52 & 88 & 100 & 13 & 39 & 61 & 3 \\
Hakwatuna & 17 & 80 & 80 & 0 & 36 & 54 & 53 & 46 & 11 \\
wa & & & & & & & & & \\
Indigolla & 75 & 47 & 51 & 28 & 17 & 37 & 0 & 36 & 13 \\
Koruwawa & 20 & 52 & 15 & 60 & 23 & 11 & 30 & 30 & 15 \\
Maeliya & 42 & 36 & 75 & 87 & 83 & 23 & 56 & 57 & 5 \\
North & & & & & & & & & \\
\hline
\end{tabular}




\begin{tabular}{lccccccccc}
\hline $\begin{array}{l}\text { Maeliya } \\
\text { South }\end{array}$ & 67 & 87 & 36 & 74 & 65 & 13 & 26 & 53 & 8 \\
Rambe & 100 & 47 & 81 & 94 & 27 & 8 & 83 & 63 & 2 \\
Rawaela & 8 & 0 & 73 & 65 & 41 & 19 & 28 & 33 & 14 \\
$\begin{array}{l}\text { Siyambalaw } \\
\text { ewa }\end{array}$ & 45 & 49 & 96 & 74 & 32 & 55 & 36 & 55 & 7 \\
$\begin{array}{l}\text { Thalkolawa } \\
\text { wa }\end{array}$ & 0 & 47 & 62 & 54 & 33 & 0 & 0 & 28 & 17 \\
Thalwahara & 15 & 76 & 100 & 68 & 19 & 15 & 100 & 56 & 6 \\
Thambuwa & 75 & 24 & 78 & 91 & 32 & 9 & 31 & 48 & 9 \\
\hline
\end{tabular}

*If the value of normalized variable is high, its' contribution to vulnerability is also high.

Table 6. Infrastructure adaptive capacity to climate change vulnerability

\begin{tabular}{|c|c|c|c|c|}
\hline \multirow[b]{2}{*}{ GN division } & \multicolumn{2}{|c|}{ Normalized variables* } & \multirow[b]{2}{*}{ Index } & \multirow[b]{2}{*}{ Rank } \\
\hline & $\begin{array}{c}\text { Un-surfaced road } \\
\text { density }\end{array}$ & $\begin{array}{c}\text { HH without } \\
\text { assured drinking } \\
\text { water }\end{array}$ & & \\
\hline Agare & 58 & 0 & 29 & 17 \\
\hline Bogolla & 89 & 70 & 79 & 6 \\
\hline Balagolla & 100 & 61 & 80 & 9 \\
\hline Dagama & 78 & 31 & 55 & 15 \\
\hline Elagamuwa & 94 & 100 & 97 & 1 \\
\hline Galtanwawa & 0 & 70 & 35 & 5 \\
\hline Hakwatunawa & 68 & 23 & 45 & 16 \\
\hline Indigolla & 76 & 46 & 61 & 13 \\
\hline Koruwawa & 88 & 33 & 61 & 14 \\
\hline Maeliya North & 77 & 72 & 75 & 4 \\
\hline Maeliya South & 89 & 64 & 77 & 8 \\
\hline Rambe & 61 & 92 & 77 & 2 \\
\hline Rawaela & 73 & 59 & 66 & 10 \\
\hline Siyambalawewa & 53 & 52 & 52 & 12 \\
\hline Thalkolawawa & 53 & 53 & 53 & 11 \\
\hline Thalwahara & 34 & 90 & 62 & 3 \\
\hline Thambuwa & 91 & 64 & 78 & 7 \\
\hline
\end{tabular}

*If the value of normalized variable is high, its' contribution to vulnerability is also high.

Sensitivity and adaptive capacity component indicators were combined and overall vulnerability of each GN divisions to climate change was assessed. According to the Figure 5, BogollaGN division is very highly vulnerable to climate change and IndigollaGN division is highly vulnerable to climate change. The reason is Bogolla is very highly vulnerable in both sensitivity and adaptive capacity while Indigolla is highly vulnerable only in adaptive capacity. Siyambalawewa, Elagamuwa, Rambe and Thambuwa are moderately vulnerable to 
climate change. Galtenwewa, Thalakolawewa, Hakwatunawa, Rawaela, Dagama and AgareGN divisions are least vulnerable to climate change.

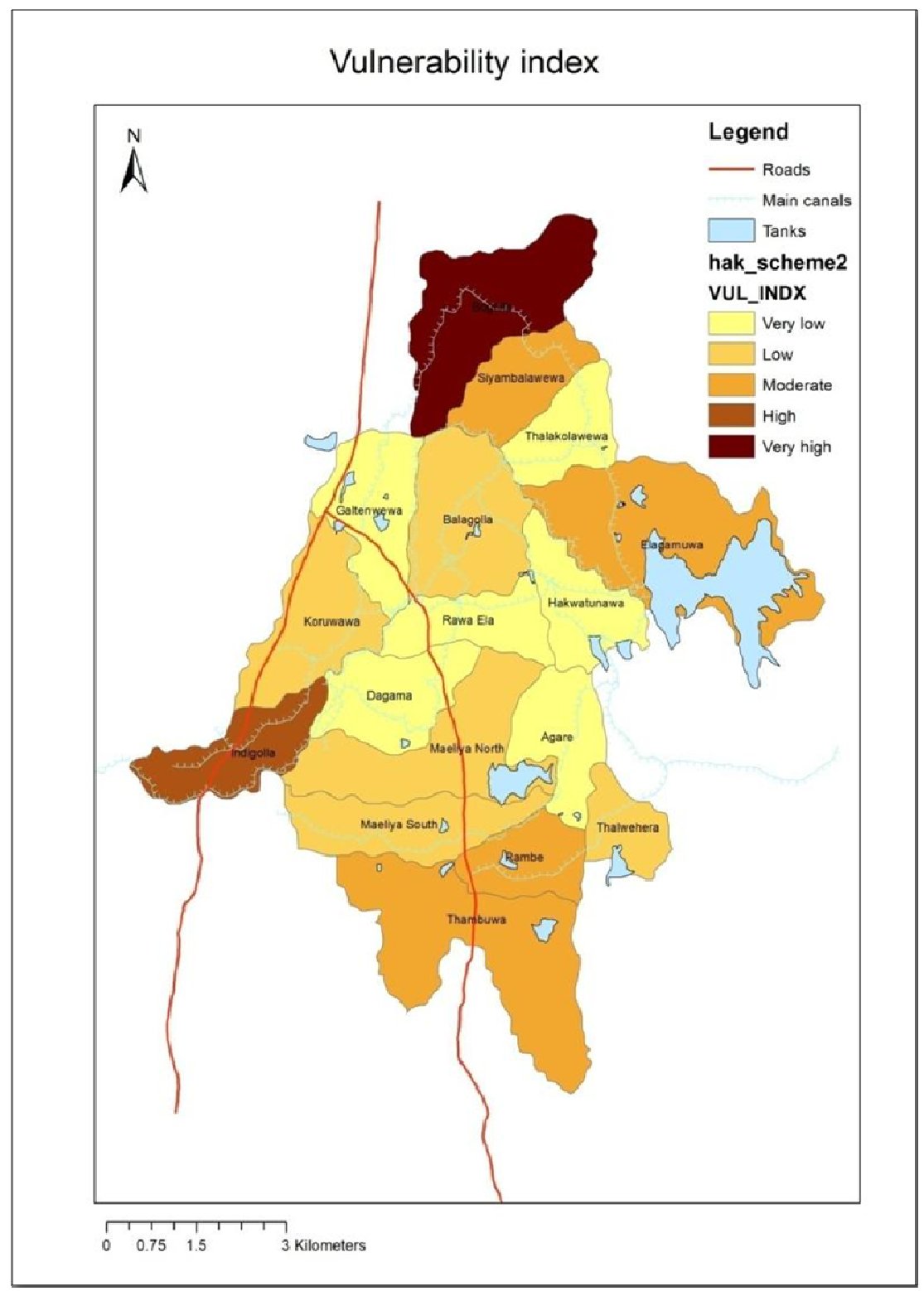

Fig. 5. Overall vulnerability of the study area to climate change

\section{CONCLUSIONS}

Sensitivity to climate change is influenced by population density, agriculture based households, area cultivated by groundwater sources and percentage of small scale farming. 
Adaptive capacity in the study area to climate change is affected by education, chronic diseases, having government of private employments, dependency, poverty, road density and assured drinking water source to farmers.

Out of $17 \mathrm{GN}$ divisions, $6 \mathrm{GN}$ divisions are moderate to highly venerable. They are Bogolla, Indigolla, Siyambalawewa, Elagamuwa, Rambe and ThambuwaGN divisions. Vulnerable GN divisions account for $38 \%$ of the land area and $41 \%$ of the population. It is suggested to consider this information in selecting GN divisions for climate change adaptation interventions.

\section{ACKNOWLEDGMENT}

This work was carried out with the aid of a grant from the International Development Research Centre (IDRC), Ottawa, Canada.

\section{REFERENCES}

IPCC.(2001) Climate Change 2001: Impacts, Adaptation, and Vulnerability. Contribution of Working Group II to the Third Assessment Report of the Intergovernmental Panel on Climate Change, McCarthy, J.J., Canziani, O.F., Leary, N.A., Dokken, D.J. and White, K.S. (Ed.), Cambridge University Press, Cambridge, 1032 p.

IPCC.(2007). Summary for Policymakers. In: Climate Change 2007: Impacts, Adaptation and Vulnerability. Contribution of Working Group II to the Fourth Assessment Report of the Intergovernmental Panel on Climate Change, Parry,M.L., Canziani,O.F., Palutikof, J.P., vander Linden,P.J. and Hanson,C.E. (Ed.), Cambridge University Press.

Eriyagama, N.,Smakhtin, V.,Chandrapala, L., Fernando, K. (2010). Impacts of climate change on water resources and agriculture in Sri Lanka: A review and preliminary vulnerability mapping. Colombo, Sri Lanka: International Water Management Institute. 51p. (IWMI Research Report 135). doi:10.5337/2010.211

MoE.(2011). Climate change vulnerability data book: Maps and data by sector. Ministry of Environment, Sri Lanka.

Punyawardena, B. V. R. (2013). Spatial variations of climate change induced vulnerability in Sri Lanka: An analysis of the components of vulnerability at district level, $40 \mathrm{p}$.

Thapa, G. (2009). Smallholder farming in transforming economies of Asia and the Pacific: Challenges and Opportunities. Discussion Paper prepared for the side event organized during the thirty third session of IFAD's Governing Council, 18 February 2009. IFAD, p. 5. 